\title{
Divriği Hospital - Medieval Healing Venue and Its Acoustic Characteristics
}

\author{
${ }^{1}$ Independent researcher, \\ Zagreb, Croatia \\ ${ }^{2}$ Art History Department, \\ Cumhuriyet University, Sivas, \\ Turkey \\ *ivana.mihaljinec@gmail.com
}

| Ivana Mihaljinec ${ }^{1, *} \mid$ Erdal Eser

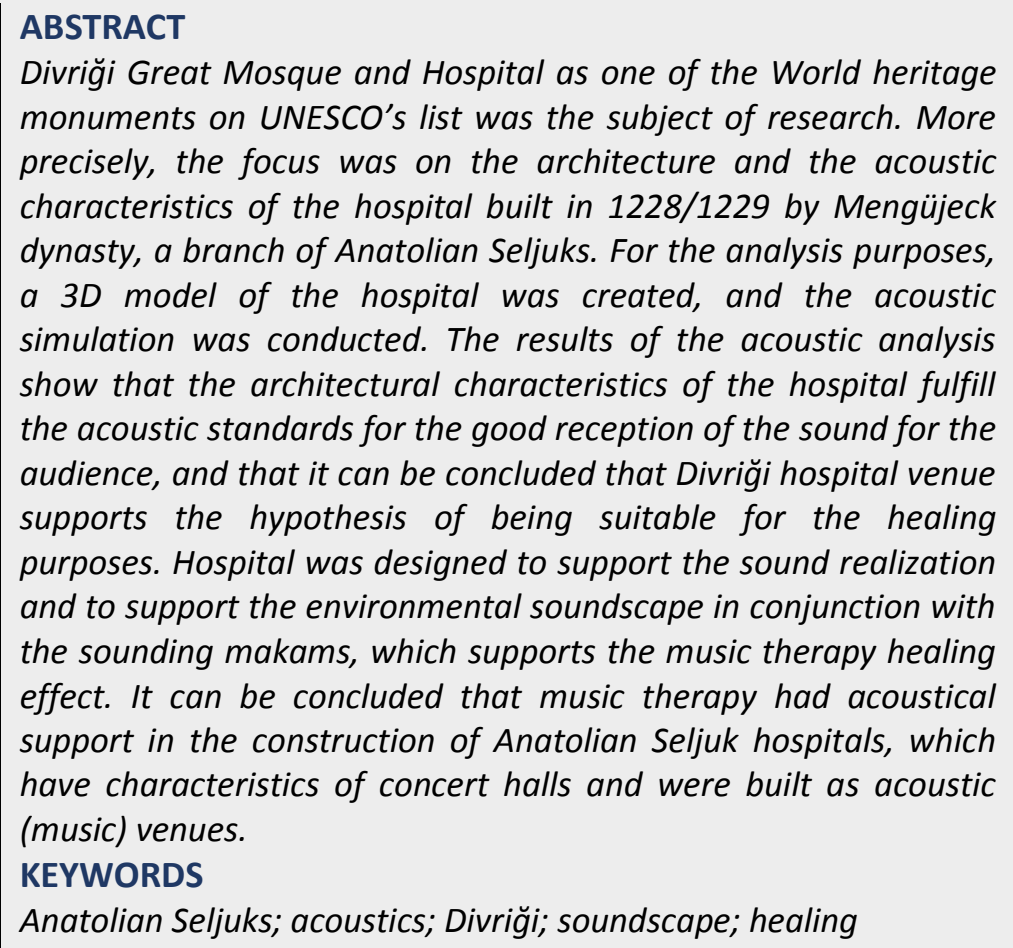
monuments on UNESCO's list was the subject of research. More precisely, the focus was on the architecture and the acoustic characteristics of the hospital built in 1228/1229 by Mengüjeck dynasty, a branch of Anatolian Seljuks. For the analysis purposes, a 3D model of the hospital was created, and the acoustic simulation was conducted. The results of the acoustic analysis show that the architectural characteristics of the hospital fulfill the acoustic standards for the good reception of the sound for the audience, and that it can be concluded that Divriği hospital venue supports the hypothesis of being suitable for the healing purposes. Hospital was designed to support the sound realization and to support the environmental soundscape in conjunction with the sounding makams, which supports the music therapy healing effect. It can be concluded that music therapy had acoustical support in the construction of Anatolian Seljuk hospitals, which have characteristics of concert halls and were built as acoustic (music) venues.

KEYWORDS

Anatolian Seljuks; acoustics; Divriği; soundscape; healing

\section{INTRODUCTION}

Divriği Great Mosque and Hospital is one of the monuments which is enrolled in the UNESCO list of World Heritage sites. Built on the leaning terrain south of the fortress in the district of Divriği in 1228-1229, it represents a work of art of the Mengüjeck dynasty, a branch of Anatolian Seljuks. This dual mosque-complex with the closed courtyard was built by Ahmet Şah and Melike Turan which is revealed by the inscription above the main entrance of the hospital, and it is the only such example for the Anatolian Seljuk legacy. The building complex itself has been described and elaborated by many scholars, but in this work, the emphasize will be on the architecture of the hospital and its acoustical characteristics.

\section{The History of Hospital Buildings}

It is important to emphasize that hospitals (şifaiye, bimarhane) built during the Seljuk and Ottoman period are different from medical and social care buildings in the rest of the world. In these institutions' priority was on improving the state of health of patients with mental disorders, treatment with the sound of music and water; a therapy known since the Roman times. The hospitals were constructed in the medieval times by various engineers (Özdemir, 1997: 19-20, Gorini, 2007:17). It can also be noticed that hospitals were built far from the cities in peaceful areas. Although all known examples today are in the city centers, at the time when they were built, they were situated outside of the city. 


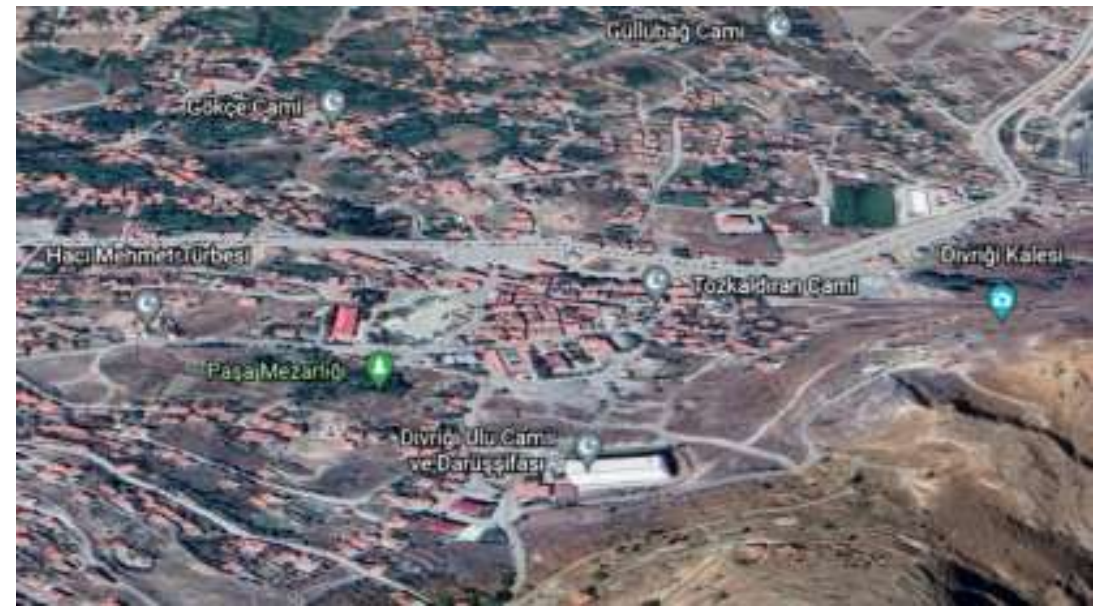

Figure 1. Aerial view of Divriği (source: Google Earth)

The choice of the place to build a hospital was made by a method which was used in the 12th century in Syria during the reign of the Zengids. The method was to hang liver on the designated spot in the city, and the edifice was built at the place where the liver started to decompose the last. This meant clear surroundings and clean air (Eser, 2012: 58). Another point that draws attention in terms of hospital buildings is that they have always been built by Sultans and their families. It is clear that the construction of healthcare buildings is considered as a kind of a task for the rulers (Eser, 2000: 139). ${ }^{1}$

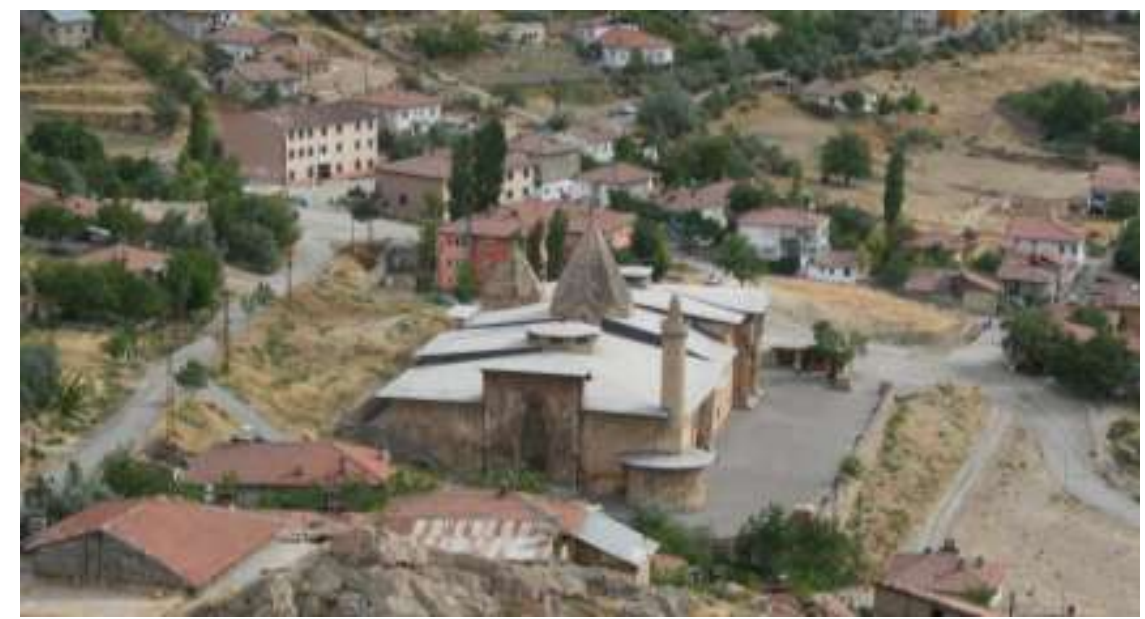

Figure 2. General view from the north (photos taken by authors)

These examples, which are preserved until today, and traces found next to the buildings show that the buildings were always constructed as twin buildings. One of them was used as a medical university and place where medical students would be trained, while the other was composed of the rooms in which patients would be examined and, in cases when it was needed, be hospitalized and treated. In addition to being built outside the residential area and as twin buildings, the architecture of the Anatolian Seljuks has no other specificities regarding the construction of the hospitals. The edifices are built according to the plans and shape of educational "institutions" (buildings). Most probably many hospitals had a dormitory for patients, as can be seen in the example of the Anber bin Abdullah Darüşşifa in Amasya (Cantay, 2014: 69).

\footnotetext{
${ }^{1}$ During the mentioned period except the hospital buildings, the Sultans also built large caravanserais on the main roads.
} 
In addition to this setting, the plan itself was obviously defined according to the courtyard shape: open courtyard and closed courtyard. If we try to relate the construction of open or closed courtyards with the climatic conditions, according to the research findings of the existing educational institution buildings, it can be seen that in almost every environment it is possible to build edifices with a closed courtyard. The most important space of the building, besides the courtyard structure, is the main iwan. This space can be the main diagnostic center, as well as, occasionally, a venue for lectures and praxis (Cantay, 2014: 69). The same space was doubtlessly used as a stage during music therapy sessions. The closed rooms between iwans can be interpreted as hospital units. It is most likely that patients stayed in those units, sometimes examinations were done, and sometimes surgeries took place.

When architectural elements of some building are considered, the terms acoustics and soundscape come as a natural flow of the sequences which form and complete the whole picture and the general idea of the medieval Islamic healing concept.

As pointed out by Çoban (2005: 54) and Giray (2008: 47), Divriği was one of the centers in the Anatolian plateau where music therapy was conducted. ${ }^{2}$

\section{RESEARCH METHODS}

In this work the reconstruction of the acoustic space of the Divriği hospital was made and the sound was revived to show how the soundscape functions within the venue. The use of music therapy has long tradition in the Islamic world since the 8th century, as it is seen in the works of al-Farabi, al-Kindi, Ibn Sina, Safiyuddin Urmevi and other scholars (Çoban, 2005: 51-58, Schimmel, 1975: 180, Uçan, 2015: 3, 10).

The Divriği hospital whose entrance is in the west is $24.00 \times 32.00 \mathrm{~m}$ in size. The central part consists of a domed courtyard and pool. The most important part of this building with two iwans is the main iwan which is on the east. The ornamentation work on the walls and top of the main iwan definitely attracts attention. The upper part of the north, south and west side of the main iwan has ornamentation in the shape of a peacock tail while the top is ornamented with a spiral which is also present in the north iwan. The entrance area of the building and its southern part are on two floors. It is believed that the venues on the upper floor were used by doctors and hospital employees. Although it is known that this edifice, which was built according to the closed madrasa plan, was used as a hospital, there is no information about the usage of individual rooms (Cantay, 1992: 51$55)$.

\footnotetext{
${ }^{2}$ Neither Giray nor Çoban give any details regarding music therapy treatment. Çoban (2006: 54) only states "1985 yılında, bu listede yer alan ilk üç varlık içinde olan Divriği Ulu Camii ve Darüşşifası da Anadolu topraklarında müzikle tedavinin uygulandığı merkezlerden biribir" (since 1985 the Divriği Mosque and Hospital are among the first three on the list (UNESCO) as centers where music therapy is applied in the Anatolian territory).
} 


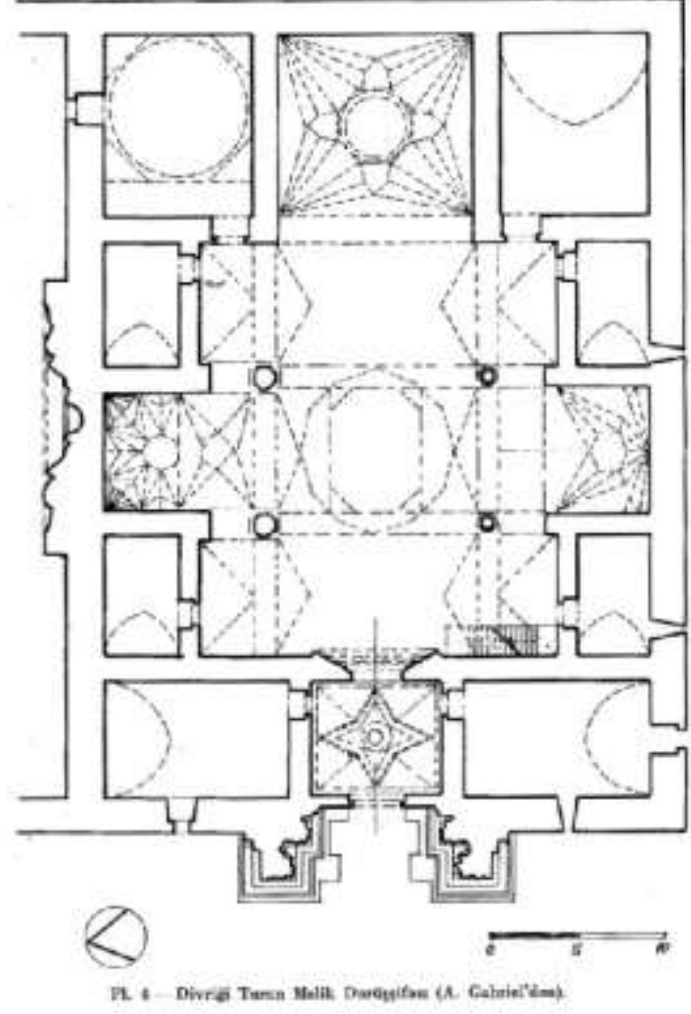

Figure 3. Cantay, 1992, plan 4

In the Islamic world the floral and geometrical composition reliefs are dominant on the façade decorations, especially mosques for religious reasons. Human reliefs were only used on hospital buildings. On the both sides of the main portal of the Divriği hospital a relief portrayal of a man's and a woman's head can be found. A little bit lower on the same building are reliefs of two winged persons facing each other, representing the builders of the Divriği complex, Ahmet Şah and Melike Turan. ${ }^{3}$
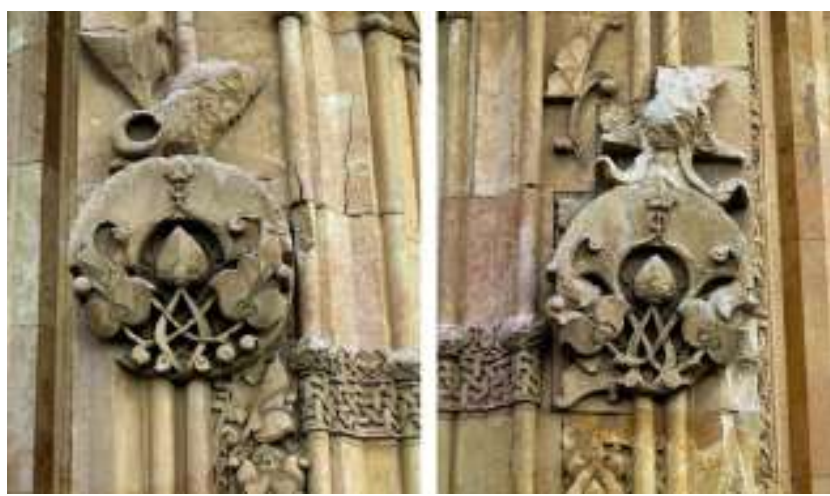

Figure 4. Man and woman reliefs, on the main door of the hospital

\footnotetext{
${ }^{3}$ In author's opinion, the architect was following the idea of an old folk story about Ferhat and Şirin and made the reliefs of the founders the same way. A new perspective regarding the ornamentation of the hospital portal is given, including portraits of Ahmet Sah and Melike Turan, stating the idea of the whole ornamentation as "a little piece of heaven captured inside stone". For more information see Eser, 2017.
} 


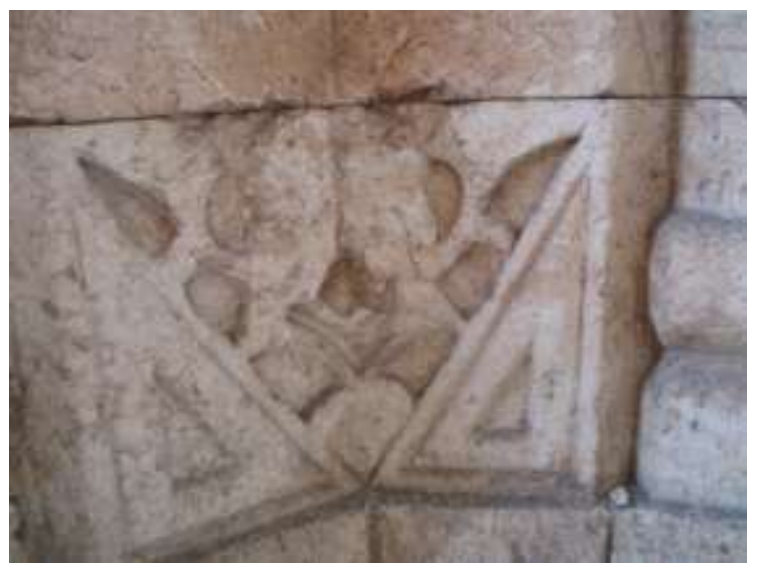

Figure 5. Two human figures, on the north side of the main door of the hospital

\section{RESULTS AND DISCUSSION}

\section{The Soundscape Concept and Architectural Features}

The soundscape concept ${ }^{4}$ can be understood from the positions where the hospitals were built, outside the city, on higher ground and with clean air, as well as in terms of architectural acoustics. ${ }^{5}$ Of course, the natural soundscapes are acoustically well designed and human design of a soundscape follows these designs through analysis of the positively functioning soundscape. The usage of certain materials such as stone and limestone is important because of the "echo" and "reverberation" effect on the listener in the venue.

The materials and techniques used for the hospital buildings seem to have high quality production characteristics. The name of the master who built Divriği Great Mosque and Hospital is Hürremşah bin Mugis el-Ahlati which is seen written in two lines on the inscription in the inner part of the outer wall. ${ }^{6}$

Quality stone production allowed the buildings to stay in good condition for a long period, while at the same time providing good heat and noise isolation. In terms of acoustics, iwans with opened walls and iwans opened towards the courtyard, with a tunnellike structure are very successfully constructed and form the shape which is good for the acoustics. Although the constructions and spaces were sometimes repaired for various reasons, the acoustical success of the buildings and spaces is still remarkable. This quality is undoubtedly a supportive factor in treatment with music. If sound is understood as a form of energy caused by vibration, this is the basis for understanding the healing potential of music. The effectiveness of the music depends on intention, providing an environment that will enhance the listening process (McClellan, 2000: 9, 179). The acoustic energy in the form of sound waves and vibration, together with people who are observing and listening, is the core of the acoustic communication model. The people who live within the soundscape are in fact creating it (Truax, 1984: 9-11).

From the general properties of the hospital buildings it can be assumed that architects in medieval Turkey had the knowledge of the soundscape idea, as architectural features point to this fact. The "Quadrivium"7 of the medieval world in which music was associated with

\footnotetext{
${ }^{4}$ For more information regarding the soundscape see Truax, 1984 and Truax, 2012. Soundscape has been used as a term since the late 1960's through different disciplines and its definition has been standardized by the Soundscape International Organization for Standardization, ISO 12913-1:2014 Acoustics Soundscape Part Definition and Conceptual Framework, ISO, Geneva, 2014.

${ }^{5}$ As Truax (1984: 12) points out "the aim of acoustic design is that desired stimulus arrives at the receiver, preventing the undesired noise to obscure the desired signal or create annoyance".

${ }^{6}$ For more information see Eser, 2017.

${ }^{7}$ See Farmer, 1926; Truax, 1984
} 
arithmetic, geometry and astronomy, presumably based on its quantitative features (Truax, 1984: 43), set the foundations for understanding soundscape and how acoustic communication works. As Merriam $(1964)^{8}$ pointed out regarding sound making in other cultures, anthropologists seem to understand that all traditional communities have a strong acoustic orientation.

In the reconstruction of the acoustic space (Mihaljinec, 2021) ${ }^{9}$ of the Divriği hospital, the idea was to revive the sound with the specific type of music which was performed in that specific venue. The intention was to show how the building sounded in the medieval time with the makam music. The complete soundscape includes the culture, spiritual and religious components as well as frequencies which are musically part of the culture (Truax, 2001: 9-11). ${ }^{10}$

The parameter of the height of the hospital is treated as one level of a sound source which determines the soundscape, whereas makams are understood as a sound source ${ }^{11}$ within the soundscape.

The architectural characteristics of the building create a soundscape which is applicable for the listeners to enter into the "safe-zone" and receive the sound signals within the space as a positive cognitive experience. Therefore, it can be used as a healing venue, not only in terms of the name itself, but also in the meaning of a response to the soundscape experience. ${ }^{12}$ The soundscape, understood as a reflection of ourselves (Rindel, 2000: 106), enhances the experienced sounds. Therefore, the effect of the received frequencies on the body and brain has a greater impact.

\section{Architectural Features}

The hospital was built as a madrasa plan featuring in the center a pool and a stage under the main iwan. The dome which arises above the pool was closed in the $18^{\text {th }}$ century with a brick roof. The outside characteristics of the hospital and the whole complex are limestone carved ornaments, a real masterpiece of Seljuk architecture.

\footnotetext{
${ }^{8}$ Merriam, 1964 in Truax, 1984:75.

9 For the purpose of the acoustic analysis which was part of Ivana Mihaljinec' doctoral dissertation, a 3D model of the Divriği hospital was created

${ }^{10}$ Regarding the soundscape, Murray Schafer states that it is any acoustic field of study which can understand musical composition, radio program and an acoustic environment as a soundscape, consisting of the heard events (1993: 10).

${ }^{11}$ The sound source is defined as source that radiates the sound equally in all directions in a free field and has a maximum instantaneous volume velocity and is emitting a wave with sinusoidal variation with time (International Electrotechnical Commission, IEC 801-29-10; IEC 801-21-33). Retrieved from http://www.acoustic-glossary.co.uk/definitions-s.htm\#sound-source. By another definition, a sound source is something that vibrates between 20 - 20,000 times per second and therefore makes a sound pressure wave. Retrieved from https://musicterms.artopium.com/s/Soundsource.htm.

${ }^{12}$ As Truax (2001: 97) points put for the venue, it is the area whose physical characteristics allow to retain its own acoustic character, an acoustic sanctuary. Truax also emphasizes that this acoustic sanctuary may be a park, a wilderness area, a valley or lake with limited access, or even an old building.
} 


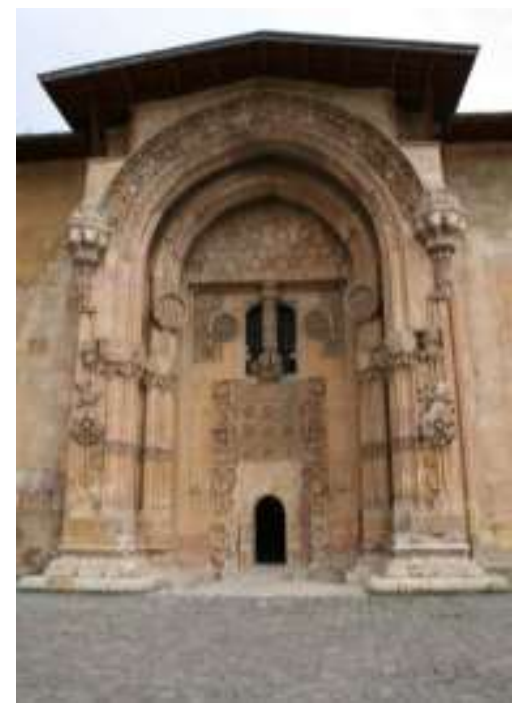

Figure 6. The main door of the hospital

The central hospital area has an area of mean volume of $1965 \mathrm{~m} 3$ and a mean surface area $958 \mathrm{~m} 2$. The surface area includes the floor and the walls, excluding the windows, doors and openings. Its size is $13.6 \times 15 \mathrm{~m}$ with a mean height of $9.63 \mathrm{~m} .{ }^{13}$ The calculation excluded the dome as this was not an original part of the hospital in the 13th century but added in the later centuries. The interior is spacious and there is no visual and auditory obstruction. It is a design consisting of multiple parts such as iwans, arcades, rooms and stairs leading from the ground floor to the first floor. The step to the main iwan, which is on the east, is $50 \mathrm{~cm}$, while the height of the iwan is $7.5 \mathrm{~m}$ and length $8.66 \mathrm{~m}$. On the south and north side there are also iwans, while the main entrance door is on the north. In the center position is the pool which was filled with water in the Seljuk time. Its inner dimensions are $2.47 \times 2.52 \mathrm{~m}$, and the surface is $6 \mathrm{~m} 2$.

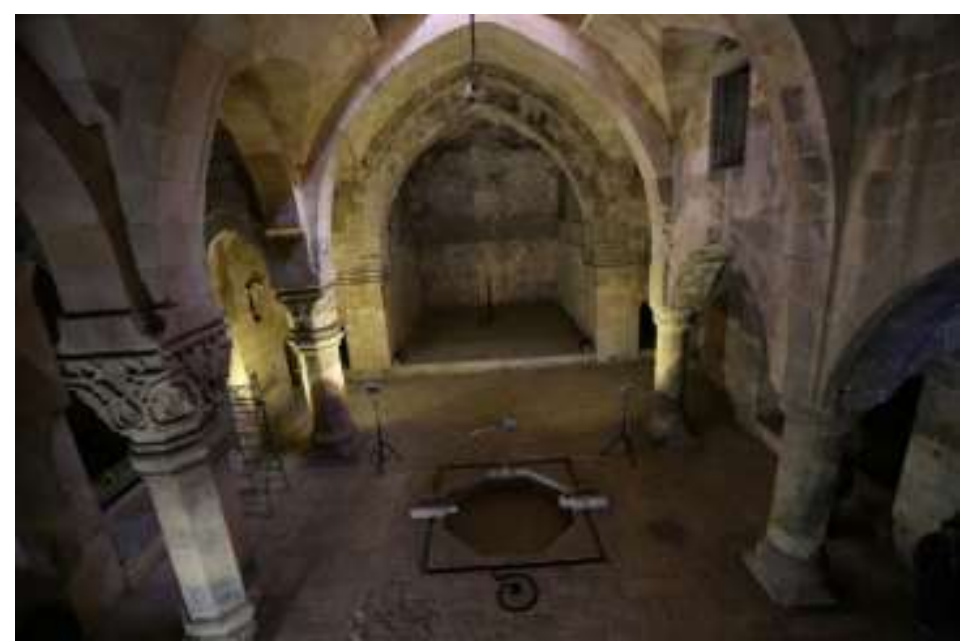

Figure 7. The main iwan and the pool, view from the west

The gallery, on which spaces and rooms are situated, due to the size of the windows was not significant in the calculation of the acoustics. The position of the stairs situated at the back door was also not significant in terms of acoustic calculations. The lateral surfaces of the hospital were made from limestone and its coefficient was used for the calculations. 13 The mean values have been taken because of the range of the slope height, which was not significant for
the calculation, so the mean value could be taken for the calculation. 
All the ornamentation inside is engraved in limestone, only the dome has some wooden construction elements, which was not significant for the acoustic parameter, as the original building did not have the roof coverage. The calculation was based on the original plan.

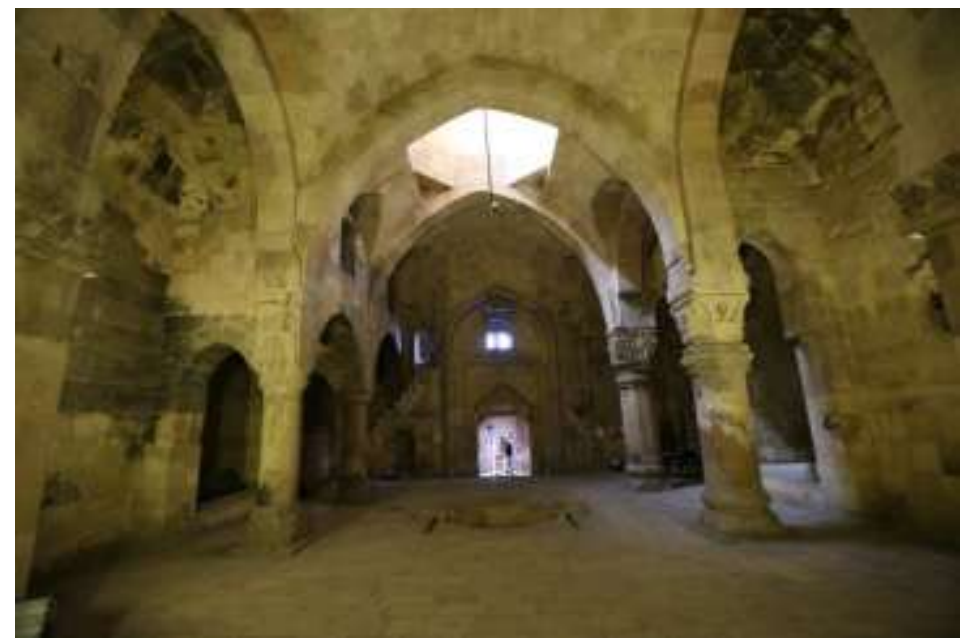

Figure 8. Inside the hospital, looking to the west

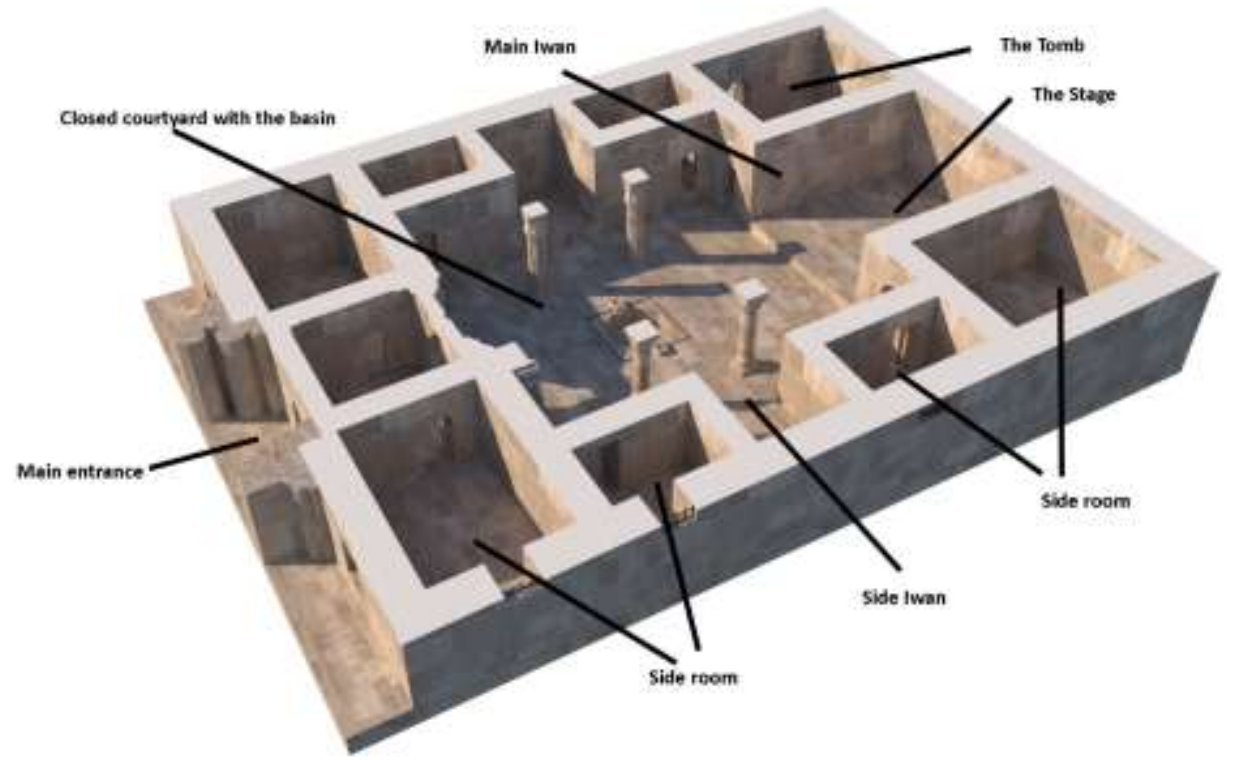

Figure 9. Cross-section of the Divriği hospital 3D model

The main objective of this analysis was to determine if the people equally hear and understand the sound coming from the main iwan stage in the Divriği hospital regardless of their standing position, by simulating the sound in a reconstructed acoustical environment. ${ }^{14}$ The acoustical environment within the room was assessed through acoustical indicators: Reverberation Time ${ }^{15}$ (RT), Early Decay Time (EDT) and Clarity. Reverberation time and Clarity are the two major perceptions which define the quality of

\footnotetext{
${ }^{14}$ The Divriği hospital is the only example with a covered courtyard from the Anatolian Seljuk architecture and as such the best preserved one. The complex of the Sultan Bayezid mosque and hospital in Edirne (1488) is believed that follows the Divriği architectural style example.

${ }^{15}$ Reverberation is easiest to notice as it is heard when music stops and sound travels, and it is possible to hear it as the music is playing. It is important for music as it makes the harmonics smooth and turns aliquots into harmony.
} 
the acoustic space. The assumption was that the hospital is the space within which music is a soundscape. As sound spreads relatively slowly, acoustic information comes to the listener at the various arrival times, making the audible image a little bit different (Truax, 1984: 15). This important feature of connecting the acoustics of the space and music which was performed for healing purposes is associated with the sound signals.

In setting up the research of architecture as a sound space, it is necessary to clarify certain parameters as referent points in the analysis.

The parameter of the height ${ }^{16}$ is treated as a sound source level which determine the soundscape. Makams were understood as a sound source within a soundscape. The keynotes are frequencies which came from repetitive sound signals of the makams.

Computer simulation of the Divriği hospital was carried out using the EASERA software $^{17}$ and ODEON room acoustic software ${ }^{18}$. The Odeon room acoustic program also takes into account the statistical properties of the room's geometry and absorption (Rindel, 2000). The hospital was 3D modeled in the SketchUp software for 3D design ${ }^{19}$ and then the calculation of the geometries within the hospital were taken into consideration. Columns and galleries were not significant for the obstruction of the sound, since the volume of the space was quite sufficient for the acoustic absorption of the sound.

From the 3D model the impulse response (IR) was modeled in Odeon (in the form of a gunshot wav file) and then analyzed in the Easera software. The distance between the omnidirectional sound source and omnidirectional microphone was $10.23 \mathrm{~m}$. For calculation purposes, length, width, height, volume, water, area and coefficient of absorption were taken into consideration in order to calculate the Reverberation Time (RT), Early Decay Time (EDT), and Clarity (C).

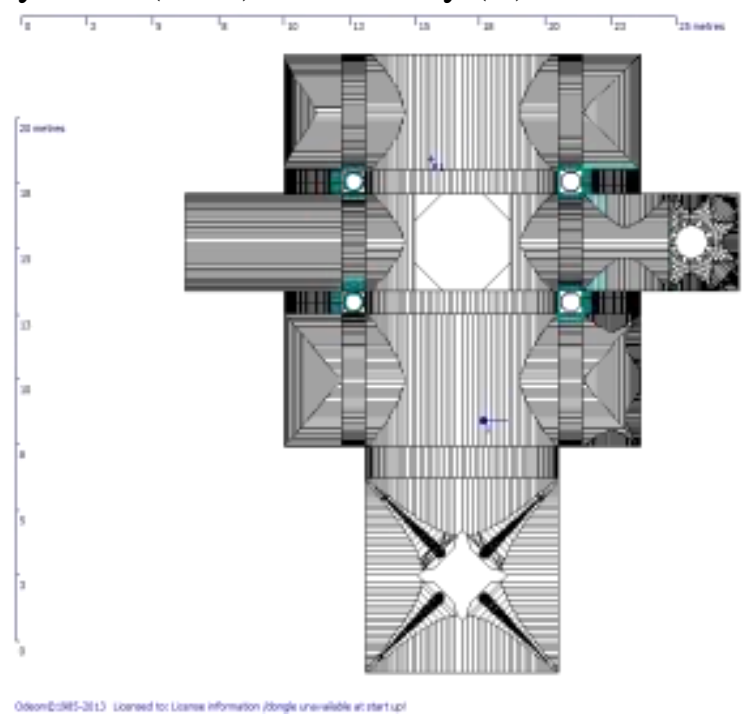

Figure 10. Inside plan of the hospital, showing the position of the sound source and microphone.

\footnotetext{
${ }^{16}$ For the purpose of calculations, the parameter of the height was important for the closure of the space and for the calculation of the reverberation time of the space/hospital.

${ }^{17}$ AFMG EASERA 1.2.13 - Electronic and acoustic system evaluation and response analysis.

${ }^{18}$ Odeon software was used for modelling the impulse response of the space. Here the authors would like to thank Prof. dr. Siniša Fajt and Dr. Miljenko Krhen from the University of Zagreb, Faculty of Electrical Engineering and Computing, Department of Electroacoustics, for acoustical calculations in the aforementioned programs, and Luka Grubišić-Čabo, m.sc.ee. for clarification of the obtained results.

${ }^{19}$ SKETCHUP PRO 16, Trimble Inc. The authors would like to thank Mario Goleš from Goleš design, for making a 3D model of the Divriği hospital.
} 
Table 1. Coefficient of sound absorption in the $125-4000 \mathrm{~Hz}$ range

\begin{tabular}{|l|l|l|l|l|l|l|}
\hline Frequency & $125 \mathrm{~Hz}$ & $250 \mathrm{~Hz}$ & $500 \mathrm{~Hz}$ & $1000 \mathrm{~Hz}$ & $2000 \mathrm{~Hz}$ & $4000 \mathrm{~Hz}$ \\
\hline$\alpha$ stone & 0.01 & 0.01 & 0.01 & 0.01 & 0.02 & 0.02 \\
\hline$\alpha$ limestone & 0.02 & 0.02 & 0.03 & 0.04 & 0.05 & 0.05 \\
\hline$\alpha$ openings & 1 & 1 & 1 & 1 & 1 & 1 \\
\hline$\alpha$ water & 0.008 & 0.008 & 0.013 & 0.015 & 0.020 & 0.025 \\
\hline
\end{tabular}

The coefficients of absorption are quantity important for measuring the sound absorption of the material and defined as the ratio of energy absorbed by the material to the energy incident upon its surface. This is needed to calculate mainly the reverberation time of the room as well as other relevant parameters of the acoustic calculations. Together with the following information about the surface area (Table 2), the formula can be used to calculate the parameters.

Table 2. Surface area of Divriği hospital in meters

\begin{tabular}{|l|l|l|l|}
\hline Surface in meters & & & \\
\hline S stone /limestone & $958.84 \mathrm{~m}^{2}$ & Width & $15.00 \mathrm{~m}$ \\
\hline S openings (doors and windows) & $20 \mathrm{~m}^{2}$ & Length & $13.60 \mathrm{~m}$ \\
\hline S water & $5.40 \mathrm{~m}^{2}$ & Volume (mean) & $1965 \mathrm{~m}^{3}$ \\
\hline
\end{tabular}

In order to calculate the acoustic surface, Sabine's formula was used RT=0.16 V/A, where RT is the reverberation time, $\mathrm{V}$ is the volume of the room and A is total absorbing power. The formula used for the absorbing power was $A_{n}=\alpha_{s}{ }^{n} \times S_{s}+\alpha_{o}{ }^{n} \times S_{o}+\alpha_{w}{ }^{n} \times S_{w}$ where $n$ was the corresponding frequency from the absorption table coefficient. The results showed a longer reverberation time in the lower frequencies, and shorter in the higher frequencies.

The hypothesis was that the hospital venue is suitable for healing purposes; the architectural characteristics of the venue support the circularity of the sound, where people were standing and/or sitting around the pool area, while the musicians were positioned in the main iwan, playing music. The number of people is variable, so it was not included as an absorption factor. ${ }^{20}$

The results obtained from the EASERA software are showed in the following figures.

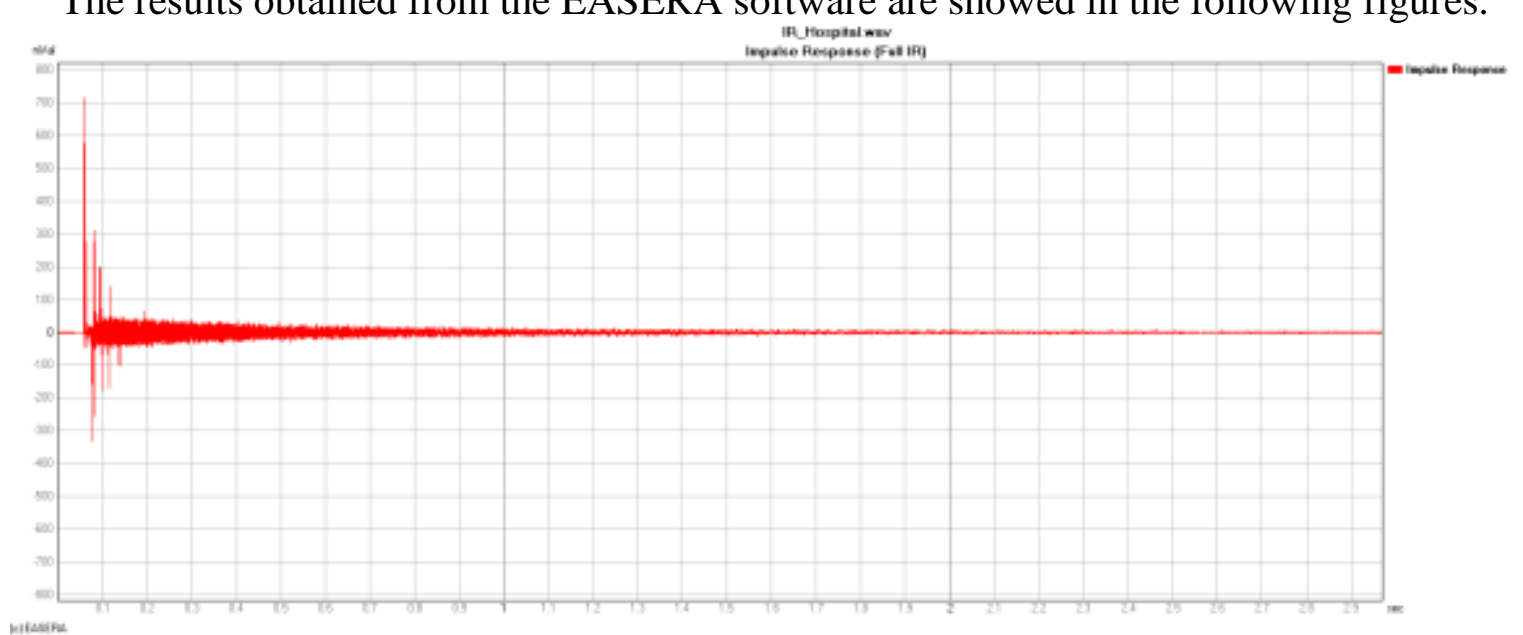

Figure 11. Impulse response

\footnotetext{
${ }^{20}$ However, as an example, the authors were present during one performance of a sound presentation in Divriği hospital in 2014, when one performer climbed up on the stage and sang a short melody from six points of the stage, facing the iwan and facing the audience, in order to show how the same amount of sound came to the listener, regardless from which point of the stage it is performed.
} 

$2.9 \mathrm{~s}$.

In this figure it can be seen that the length of the impulse response of the gunshot was

Table 3. Impulse response (Full IR)

\begin{tabular}{|c|c|c|c|c|c|c|c|c|c|c|}
\hline $\mathrm{C} 7$ & $\mathrm{C} 50$ & $\mathrm{C} 80$ & $\mathrm{D}$ & $\mathrm{L} 7$ & L50 & L80 & Center time & ST1 & ST2 & Arrival time \\
\hline $\mathrm{dB}$ & $\mathrm{dB}$ & $\mathrm{dB}$ & & $\mathrm{dBFS}$ & $\mathrm{dBFS}$ & $\mathrm{dBFS}$ & $\mathrm{ms}$ & $\mathrm{dB}$ & $\mathrm{dB}$ & $\mathrm{ms}$ \\
\hline-9.7 & -4.9 & -2.9 & 0.242 & -0.7 & 3.3 & 4.8 & 305.33 & 4.8 & 7 & 59.68 \\
\hline
\end{tabular}

C7 is the direct sound measure for the sensation of the directness and nearness of the sound source and is one of the sound-source criteria (Easera, 2012: 6). In correlation to the distance from the sound source-listener ${ }^{21}$ should not fall below a range of -10 to $-15 \mathrm{~dB}$. In our calculation the result is $-9.7 \mathrm{~dB}$ which is satisfactory for this criterion.

C50 is the clarity measure relevant to speech performance. The higher the value, the higher the intelligibility.

C80 is the clarity measure (according to ABDEL ALIM) which is relevant for the temporal clarity and the register clarity of music performance. There are no normative room acoustical rules, however, it is stated that less then $-5 \mathrm{~dB}$ for sacral music is acceptable, and up to $-1.6 \mathrm{~dB}$ for classical music is acceptable (Easera, 2012: 34-35). Therefore, our result of $-2.9 \mathrm{~dB}$ is acceptable and satisfactory for the clarity in the hospital.

$\mathrm{D}$ is for "definition" and is a room-acoustical criterion for the intelligibility quality of speech performances (Easera, 2012: 17). The recommended value is less than 0.5. In this work's the calculation value is 0.242 which is satisfactory for this "seat-related listener criteria".

$\mathrm{L}$ is for level function and is used to calculate the sound pressure levels from an impulse response. The results show the quantities of levels 7 (L7), 50 (L50) and 80 (L80) ms (Easera, 2012: 134).

The Center Time is the point where the energy received before the time is equal to the energy received after the time. For satisfactory speech intelligibility it should be below 130 ms. For music, a partially delayed response is rather acceptable or even desirable (soft sound build-up) (Easera, 2012: 135). Our results show the $305.33 \mathrm{~ms}$, which suggests a soft sound build-up for the music.

Support ST is a measure for the acoustical support by the sounding room in the stage area, where ST1 is a measure for mutual hearing on the stage and ST2 is a measure showing the room response (Easera tutorial, 2012: 133).

The Arrival Time is the period between start of the measurement and the arrival of the signal, which means a certain level above noise (Easera tutorial, 2012: 129). In our case, this arrival time is $59.68 \mathrm{~ms}$.

\footnotetext{
${ }^{21}$ For this calculation, listeners were not actually included, but measurement setting instead.
} 


\section{Specific Measurements}

Reverberation time

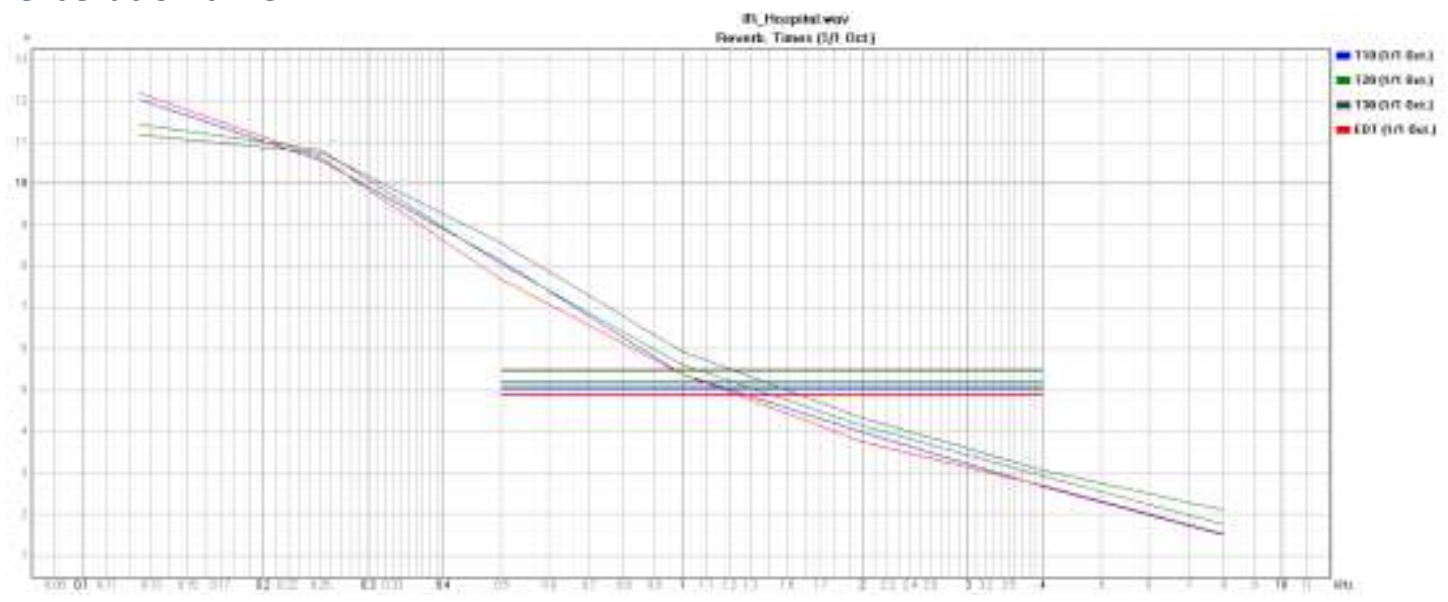

Figure 12. Reverberation Time

The Reverberation Time is the global quantitative criterion of the sound field in a room which gives fullness and richness to the music. But, in order to get the accurate results, two types are measured-Early Decay Time and Reverberation Time as T10, T20 and T30 (T10 represents even sound distribution in the room and approximately 20 sound reflections within $10 \mathrm{~ms}$, T20 within $20 \mathrm{~ms}$ and T30 within $30 \mathrm{~ms}$ ) (Easera, 2012: 8, 20). They are "overall parameters" in the assessment of the room-acoustic quality [17; p.6]. RT is determined by these parameters where the ISO 3382 (Kürer and Kürzer, 1967/68: 313) across the energy ranges is $-5 \mathrm{~dB}$ to $-15 \mathrm{~dB}$ (for $\mathrm{T} 10$ ), $-5 \mathrm{~dB}$ to $-25 \mathrm{~dB}$ (for $\mathrm{T} 20$ ) and $-5 \mathrm{~dB}$ to $-35 \mathrm{~dB}$ (for T30) (Easera, 2012: 14).

Table 4. Reverberation Time

\begin{tabular}{|l|l|l|l|l|l|l|l|}
\hline & $125 \mathrm{~Hz}$ & $250 \mathrm{~Hz}$ & $500 \mathrm{~Hz}$ & $1000 \mathrm{~Hz}$ & $2000 \mathrm{~Hz}$ & $4000 \mathrm{~Hz}$ & $8000 \mathrm{~Hz}$ \\
\hline & $\mathrm{s}$ & $\mathrm{s}$ & $\mathrm{s}$ & $\mathrm{s}$ & $\mathrm{s}$ & $\mathrm{s}$ & $\mathrm{s}$ \\
\hline EDT & 12.18 & 10.63 & 7.68 & 5.39 & 3.76 & 2.69 & 1.53 \\
\hline T10 & 12.03 & 10.56 & 8.13 & 5.39 & 3.98 & 2.68 & 1.51 \\
\hline T20 & 11.44 & 10.81 & 8.06 & 5.61 & 4.15 & 2.93 & 1.76 \\
\hline T30 & 11.19 & 10.74 & 8.57 & 5.94 & 4.32 & 3.08 & 2.10 \\
\hline
\end{tabular}

The early part of sound decay determines better how the audience perceives music, and a measure for this is Early Decay Time (EDT) [21]. It is calculated by measuring the amount of time it takes sound energy to decay the first $10 \mathrm{~dB}$ and multiplying that by six. The shorter EDT improves clarity, and longer RT provides liveness of music. The results of the analysis in the table show that in the lower frequencies the Early Decay Time (EDT) and decay time 10-30 seconds have a longer response. The Reverberation Time is the time that passes after an acoustic source in a room has been turned off, until the sound energy density has decreased to $1 / 1.000 .000$ of the initial value or until the sound pressure has decayed to 1/1000, i.e. by $60 \mathrm{~dB}$ (Easera, 2012: 17). 


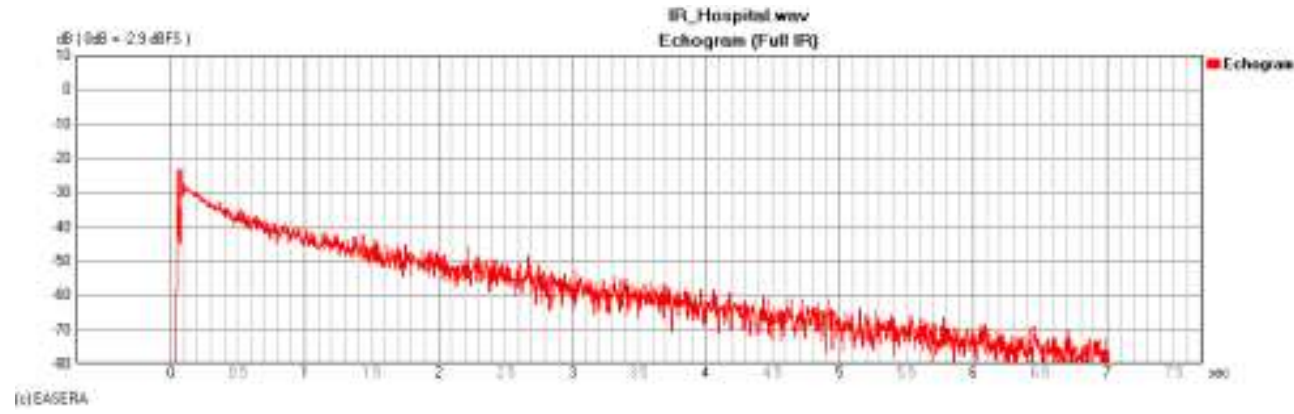

Figure 13. Echogram

In contrast with the Reverberation Time, where RT is the sound travelling from the source to a certain point, echo is a sound which is a result of the bouncing of the sound coming to a certain point. If the echo is too large, there will be distortion of sound; if it is too small, the sound will be "dry". The results show fast decay of the echo, meaning that it is not too large and therefore, is not distorting the sound.

\section{Clarity measures}

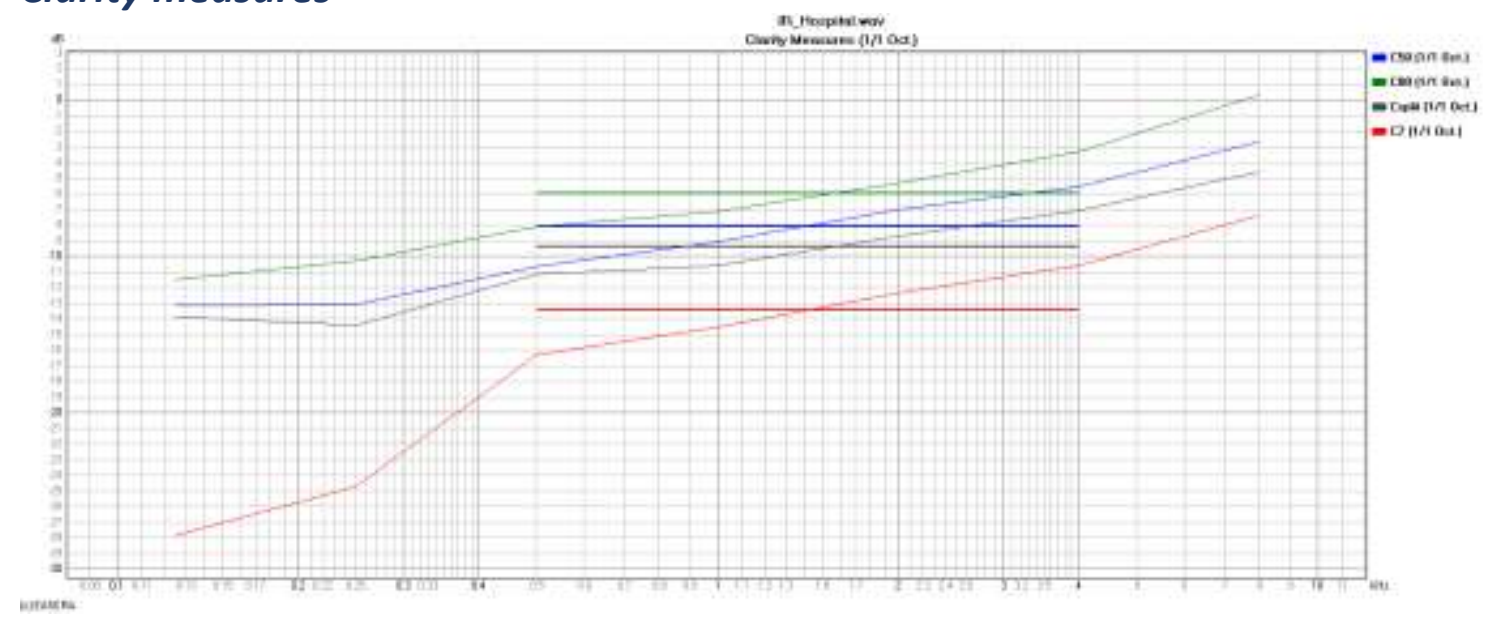

Figure 14. Clarity measures

The measurement of Clarity is the ratio of the energy in the early sound which is heard in the first $80 \mathrm{~ms}$ after the arrival of the direct sound, compared to the ratio of the energy in the reverberant sound, expressed in decibels $(\mathrm{dB})$. It shows the degree to which the individual sounds stand apart from one another ${ }^{22}$.

Table 5. Clarity measures

\begin{tabular}{|l|l|l|l|l|l|l|l|}
\hline & $125 \mathrm{~Hz}$ & $250 \mathrm{~Hz}$ & $500 \mathrm{~Hz}$ & $1000 \mathrm{~Hz}$ & $2000 \mathrm{~Hz}$ & $4000 \mathrm{~Hz}$ & $8000 \mathrm{~Hz}$ \\
\hline & $\mathrm{dB}$ & $\mathrm{dB}$ & $\mathrm{dB}$ & $\mathrm{dB}$ & $\mathrm{dB}$ & $\mathrm{dB}$ & $\mathrm{dB}$ \\
\hline C7 & -27.8 & -24.7 & -16.3 & -14.5 & -12.4 & -10.6 & -7.4 \\
\hline C50 & -13.1 & -13.1 & -10.6 & -9.1 & -7 & -5.6 & -2.7 \\
\hline C80 & -11.5 & -10.3 & -8.1 & -7.1 & -5.3 & -3.3 & 0.3 \\
\hline C split & -13.8 & -14.4 & -11.1 & -10.6 & -8.7 & -7.1 & -4.6 \\
\hline
\end{tabular}

\footnotetext{
${ }^{22}$ http://www.bnoack.com/index.html?http\&\&\&www.bnoack.com/acoustic/concerthall.html
} 
Clarity depends on the physics of the space and will be reduced for the effort of increasing the reverberation. But, as can be seen in the table, C80 in the low frequency clarity goes from $-11.5 \mathrm{~dB}$ to $-7.1 \mathrm{~dB}$, which means that clarity is understandable for music and also for speech. As the neural mechanism is time-dependent for detecting harmonic coherence, the long reverberation time and low clarity provide richness of sound, thus making the sound experience stronger and more significant.

The frequency response (amplitude frequency characteristic in the reception site) was calculated (from the impulse response with Fourier's transformation of frequency response) for an answer regarding whether the space supports or annulate specific frequencies. The value expressed as dBFS refers to decibels full scale which means that it has a defined maximum peak level ${ }^{23}$.

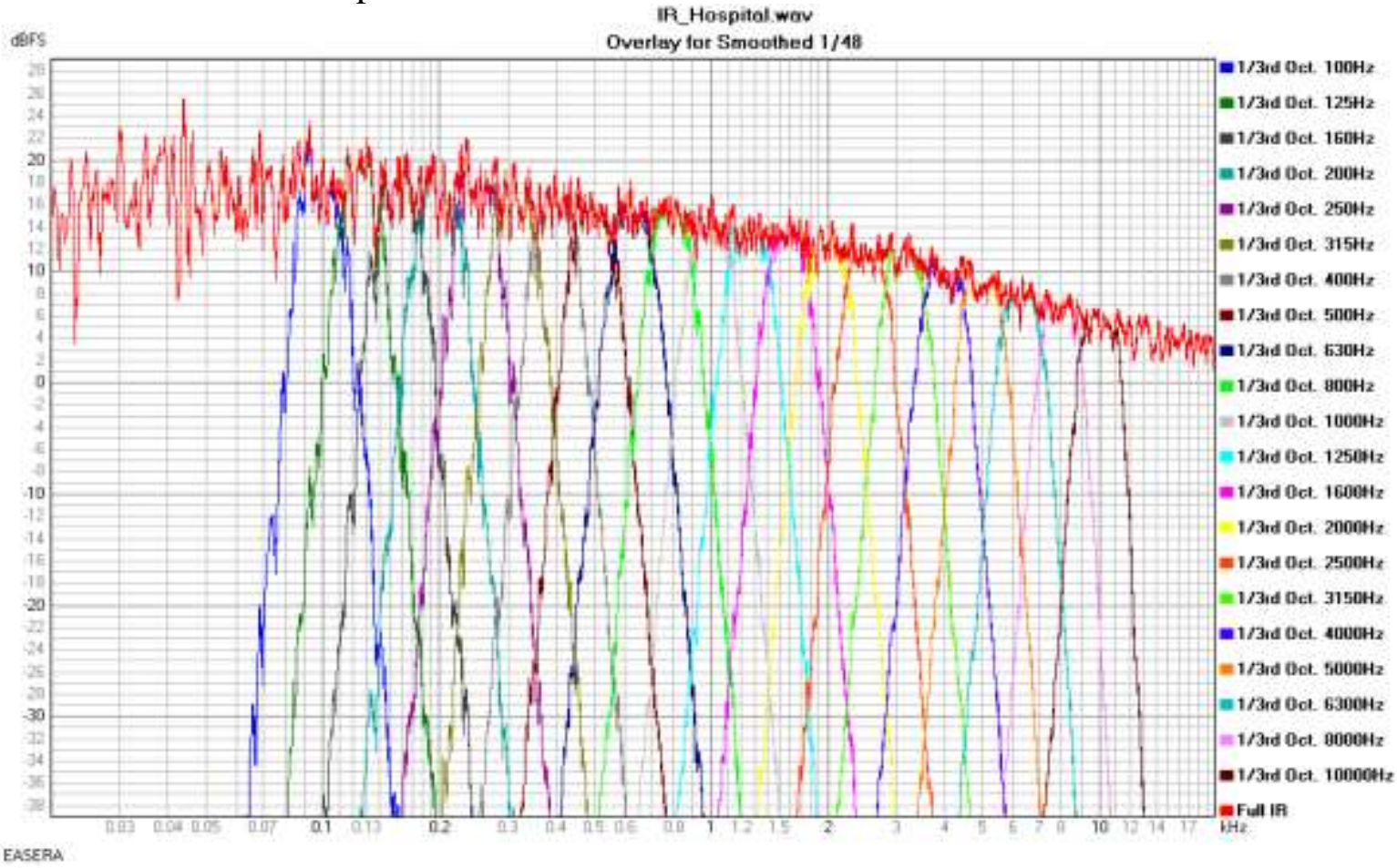

Figure 15. Overlay of the impulse response

Specific frequencies can be observed on this graph, corresponding with the peak tones retrieved from the makam analysis $(\mathrm{G}=378 / 385 \mathrm{~Hz}, \mathrm{~A}=432 / 440 \mathrm{~Hz}, \mathrm{Bb}=460.8 / 469.3 \mathrm{~Hz}$, $\mathrm{C}=518.4 / 586.6 \mathrm{~Hz}, \mathrm{D}=648 / 660 \mathrm{~Hz}, \mathrm{E}=720 / 733 \mathrm{~Hz}) .{ }^{24}$ This result shows dB full scale, where $0 \mathrm{dBFS}$ represents the highest possible level in the digital gear with no clipping of the frequencies. ${ }^{25}$

The graph shows that specific frequencies peak with the impulse response, indicating a smoothing decay in the higher frequencies.

As the frequency raises, the response time shortens, which can be observed in the next figures of the spectrogram and waterfall.

\footnotetext{
${ }^{23} \mathrm{http}$ ///www.audiomasterclass.com/newsletter/what-is-the-difference-between-0-db-and-0-dbfs

${ }^{24}$ For the analysis of the makams and the result regarding their frequencies see Mihaljinec (2021) [8].

${ }^{25}$ For detailed information regarding dBFS see http://www.jimprice.com/prosound/db.htm; For the noise level see chart https://www.noisehelp.com/noise-level-chart.html.
} 


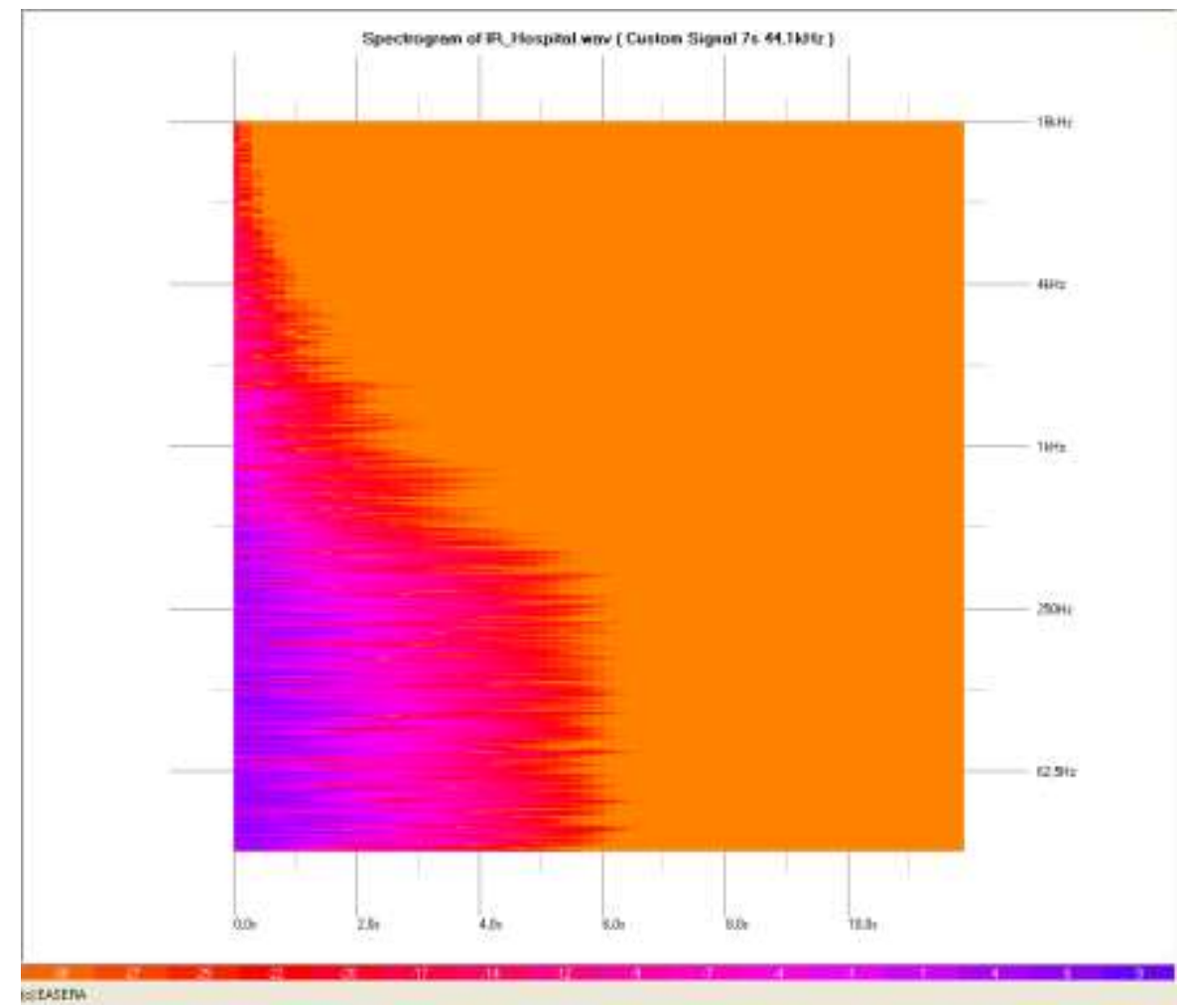

Figure 16. Impulse response spectrogram

The minimal criterion to ensure a balance between various sounds is that their spectral energy is distributed over different parts of the audible frequency range (Truax, 1984: 73), which is visible on this example of the Divriği Hospital.

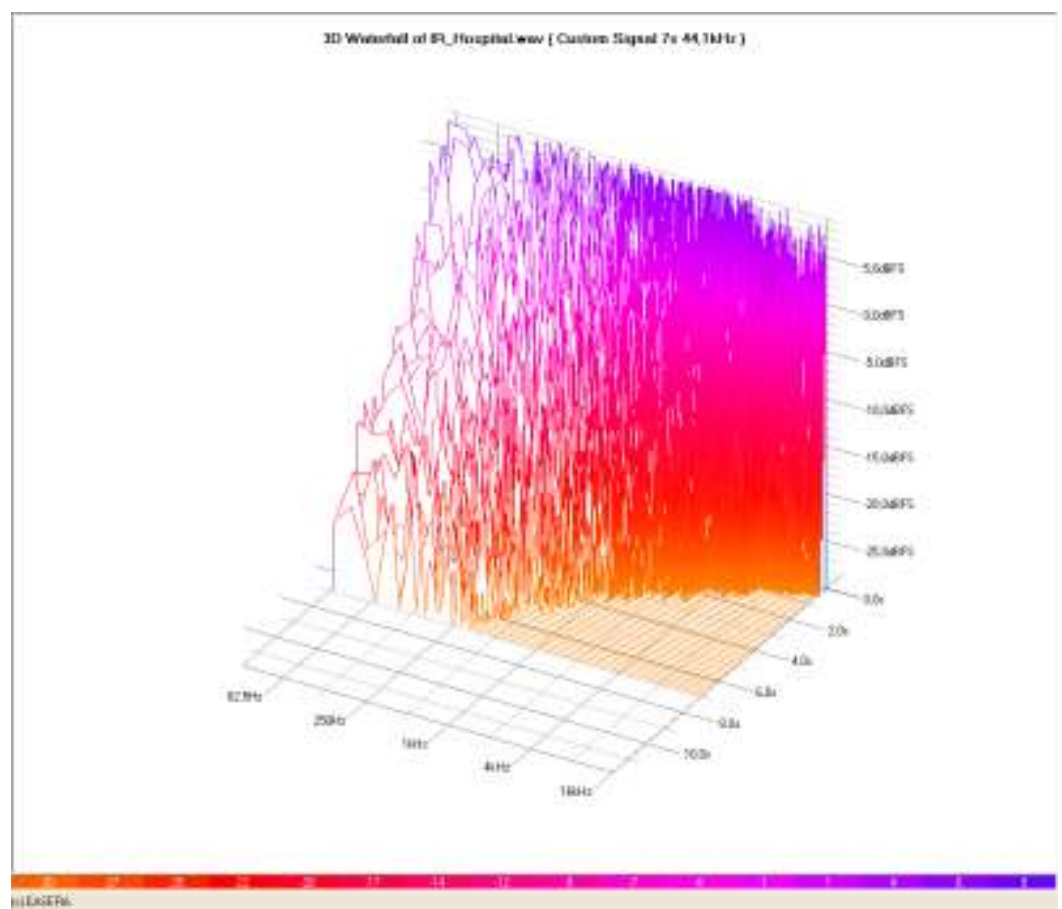

Figure 17. 3D waterfall of impulse response 


\section{CONCLUSION}

When the cross section of all the results given above is observed, it can be seen that the room response is satisfactory for music standard measurement (C80, RT, EDT, T10, T20, T30). As Reverberation time is determined by measuring the sound level decay in a range from $-5 \mathrm{~dB}$ to $-35 \mathrm{~dB}$ for $\mathrm{T} 30$, and the Early decay time and $\mathrm{T} 10$ range $0 \mathrm{~dB}$ to $-10 \mathrm{~dB}$ are more in conformity with subjective assessment of the duration of reverberation, especially at low-level volumes, it can be seen that the results of clarity measures and reverberation time are meeting the given standards of the room-acoustic parameters.

It can be concluded that architectural characteristics of the Divriği hospital fulfill the acoustic standards for the good reception of the sound for the audience. From this acoustic analysis it can be concluded that Divriği hospital venue supports the hypothesis of being suitable for the healing purposes. The acoustic analysis also showed that the sound realization could take place in the hospitals which were designated to support it, and to support the environmental soundscape in conjunction with the sounding makams. The results showed that the reverberation time and clarity are similar to concert halls and therefore create a suitable soundscape, supporting the music therapy's healing effect.

Overall, the results have shown that hospitals from the Anatolian Seljuk period had characteristics of concert halls and were built as acoustic (music) venues. The music therapy which was conducted in those venues had acoustical support in the construction, and some building examples show a pool in the middle of a closed courtyard, where water was in constant flow, which was very important for the community for religious and health reasons. The specific makam frequencies in conjunction with the acoustic design of the venue form a positive soundscape which has a mild and healing effect on the listeners/patients.

\section{REFERENCES}

Arda, Berna. (2009). Anatolia; The Cradle of Modern Medicine. Ankara Üniversitesi Tip Fakültesi Mecmuasi, 62(1), pp.8-12.

Cantay, Gönul. (1992). Anadolu Selçuklu ve Osmanli Darüssifalari. Atatürk Kültür, Dil ve Tarih Yüksek Kurumu, Ankara.

Cantay, Gönul. (2014). Anadolu Selçuklu ve Osmanli Darüssifalari. Atatürk Kültür Merkezi Baskanligi, Ankara.

Çoban, Adnan. (2005). Müzikterapi. Timas Yayinlari, Istanbul.

Eser, Erdal. (2000). 11.-14. Yüzyıl Anadolu-Suriye Sanat Iliskileri (Cephe Mimarisinde

Suriye Etkileri). Hacettepe Üniversitesi, Sosyal Bilimler Enstitüsü, Unpublished doctoral thesis, Ankara.

Eser, Erdal. (2012). Bir Mucizenin Düsündürdükleri. Hayat Agaci Dergisi, 19, pp.55-62.

Giray, Hayriye Serenay. (2008). Treatment with Music Down the Ages and Diseases It is Applied in. T.C. Kocaeli University Social Sciences Institute, Principal Art Branch of Music, Postgraduate Thesis of the Department of Musicology, Kocaeli.

Gorini, Rosanna. (2007). Bimaristans and Mental Health in Two Different Areas of the Medieval Islamic World. Journal of the International Society for the History of Islamic Medicine (ISHIM), vol. 6-7, no.11-14, pp.16-20.

Kürer, R., Kürzer, A. (1967/68). Integrationsverfahren zur Nachhallauswertung (Integration procedure for evaluating reverberation), Acustica 19, p.313.

McClellan, Randall. (2000). The Healing Forces of Music: History, Theory and Practice. Lincoln: Universe.com Inc.

Mihaljinec, Ivana. (2021). Music as Healing in the Anatolian Seljuk Times. University of Zadar, Humanities, Ethnology and Anthropology, Doctoral Thesis, Zadar. 
Özdemir, Nurdane. (1997). Anadolu Halk Kültüründe, Resim, Heykel ve Müzigin Yeri, Önemi. Nurol Matbaa, Ankara.

Rindel, Jens Holger. (2000). The use of computer modeling in room acoustics. Journal of Vibroengineering, 3(4), pp.219-224.

Schimmel, Annemarie. (1975). Mystical Dimensions of Islam. The University of North Carolina Press.

Uçan, Ali. (2015). Geçmisten Günümüze, Günümüzden Gelecege Türk Müzik Kültürü. Evrensel Müzik ve Yayinevi, Ankara.

Truax, Barry. (1984). Acoustic Communication. Ablex Publishing Corporation, Westport, Connecticut.

Truax, Barry. (2001). Acoustic Communication. Second edition. Ablex Publishing Corporation. Greenwood Publishing Group, Westport, Connecticut. 